\title{
The predator-prey interaction between blue-bearded bee eaters (Nyctyornis athertoni Jardine and Selby 1830) and giant honeybees (Apis dorsata Fabricius 1798)
}

\author{
Gerald KASTBERGER $^{\mathrm{a} *}$, D.K. SHARMA ${ }^{\mathrm{b}}$ \\ a Department of Zoology, University of Graz, 8010 Graz, Universitätsplatz 2, Austria \\ ${ }^{\mathrm{b}}$ Department of Zoology, Gauhati University, Assam, India
}

(Received 28 January 2000; revised 5 July 2000; accepted 22 September 2000)

\begin{abstract}
We investigated the interaction between raiding blue-bearded bee eaters (Nyctyornis athertoni) and counter-attacking bees in an aggregation of 50 giant honeybee (Apis dorsata) colonies on a bee tree in Assam, India. We filmed two scenarios with an Arriflex camera at 150 frames per second: first, the bee eater passed parallel to a nest, threatening only the sunny side of the colony, and second, the bird passed a nest laterally in a perpendicular direction, eliciting release of a great number of guard bees from both sides of the colony. In the first scenario, we assessed more than 700 bees in the mass release, comprising 2-3 per cent of colony members. We found the first evidence for intercolonial group defence in Apis dorsata, which means that colonies or parts of them, which were not directly threatened, joined the defence action of the threatened colony. We discuss how unthreatened nests or parts of them can be challenged for mass release of guard bees.
\end{abstract}

Apis dorsata / giant honeybee / bee eater / predator-prey interaction / defence behaviour

\section{INTRODUCTION}

Wasps and birds like drongos, swallows, honey buzzards and bee eaters are the major natural predators of giant honeybees Apis dorsata [14] and A. laboriosa [19, 20]. In response to these pressures, Apis dorsata has evolved a set of behavioural strategies
$[2,14,15,18]$, which include the ability to display various imposing forms of antipredator behaviour $[2,7,8,9,11,17,18]$. Mass release of guard bees is the most impressive strategy to repel predators $[11,12,14,19$, 20]. Thousands of bees may be deployed within seconds, to pursue the invader for distances of a kilometre or more $[12,16]$.

* Correspondence and reprints
E-mail: gerald.kastberger @ kfunigraz.ac.at 
In the present study, we investigated some of the temporal and spatial cues of interaction between raiding bee eaters and counter-attacking bees. Bee eaters show a variety of species-specific strategies. We consider two scenarios of raiding bluebearded bee eaters (Nyctyornis athertoni) in an aggregation of giant honeybee colonies on a bee tree in Assam, India.

\section{MATERIALS AND METHODS}

\subsection{Observation of raiding flights}

In November 1998 we filmed in Kulsi (Assam, India), on an Arriflex camera at 150 frames per $\mathrm{s}$, the raids of blue-bearded bee eaters (Nyctyornis athertoni). This filming happened in the canopy of a $50 \mathrm{~m}$ tall Bhellu tree (Trewia nudiflora) from
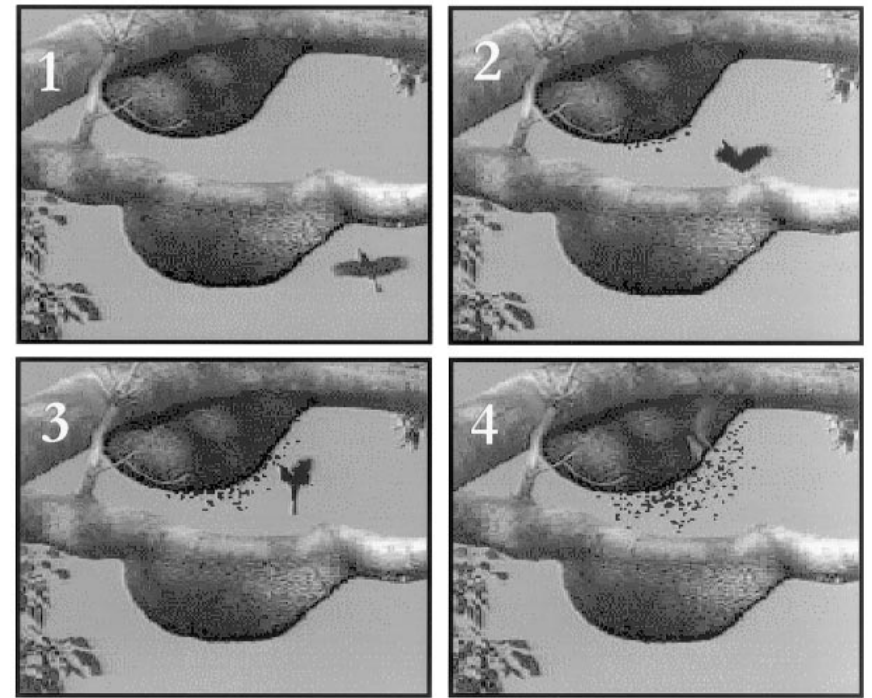

Figure 1**. How blue-bearded bee eater (Nyctyornis athertoni) alerted colonies (nest one, nest two) of giant honeybee (Apis dorsata) in the canopy of a bee tree in Assam (scenario I, see Fig. 2). The frames 1-4 were recorded at the following relative times: 0, 127, 160, $226 \mathrm{~ms}$, the frame interval was $6.66 \mathrm{~ms}$ (according to 150 frames per s); the bee eater raided the upper nest (nest one) and wiped bees off with its wings; on frame 3 it is shown how the bee eater reduced its speed. The bees are released from the rim and from the sunny side of nest one, before the bird had reached this nest (frame 2-4). In frame 4 the bird is still visible as bright stripes in nest one. Both nests had a horizontal width of about $120 \mathrm{~cm}$. The emitted bees had been artificially contrasted, the blue of the sky was turned to white.

** The video is available at: http://www.edpsciences.org/docinfos/INRA-APIDO 


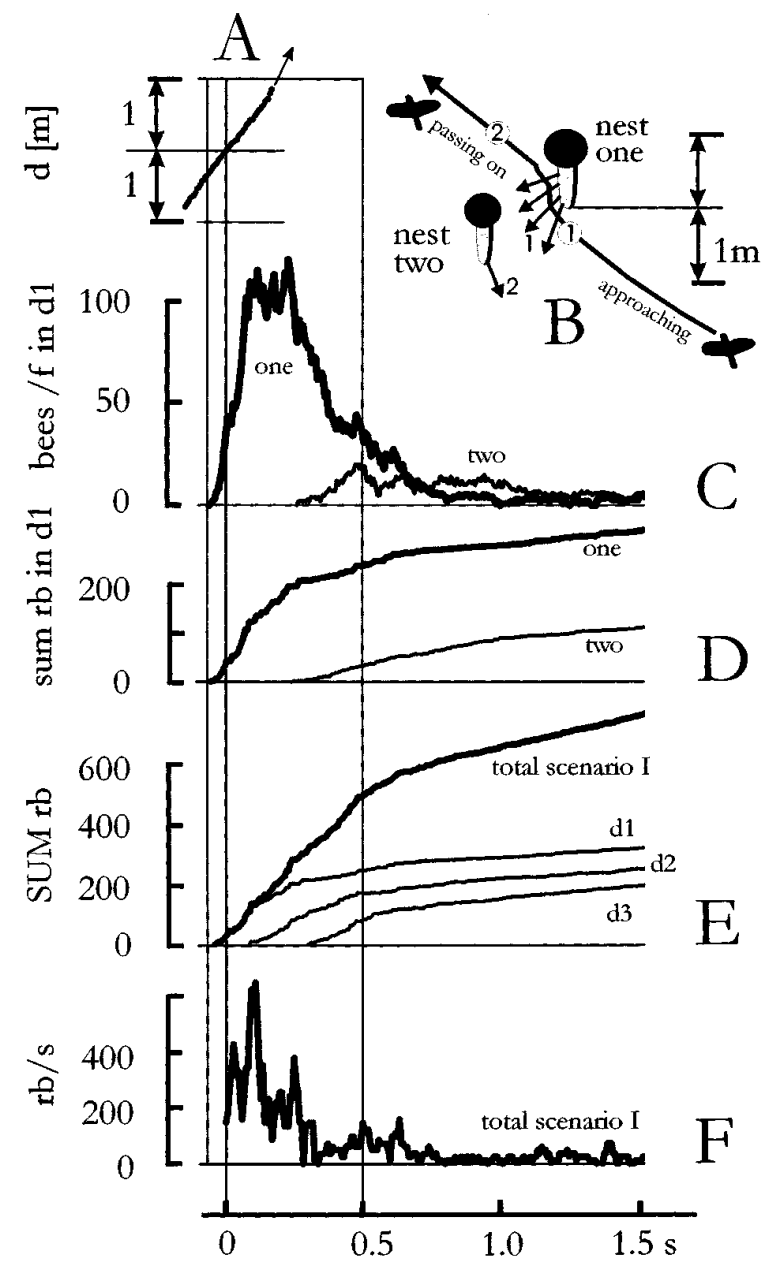

Figure 2. How a blue-bearded bee eater (Nyctyornis athertoni) attacked a colony of giant honeybee (Apis dorsata) and how that (nest one) and a neighbouring (nest two) colony reacted with a counterattack (scenario I). (A) time-distance profile of the flight course of the raiding bee eater when approaching and when passing on; d, distance between the beak of the bird and the lower rim of nest one; scales in $\mathrm{m}$; (B) sketch of nest sites from the side; nest one was threatened directly by this bee eater's raid; the bee eater approached nest one, the bees of the sunny side of nest one started to swarm off when the bird was at position 1; nest two started slight release of bees at bird position 2; the shaded sides of the nests are marked by a darker rim; scales in $\mathrm{m}$; $(\mathbf{C})$ bees / $\mathrm{f}$ are counts of bees (per frame) emitted by nest one respectively two within $\mathrm{d} 1$ (30-100 cm around the nests, see methods); (D) sum rb, the cumulative frequency of bees released (see methods) from the respective nests within d1; (E) SUM rb is the cumulative frequency of bees counted in the whole site of both the nests after the raiding attack of the bee eater; the curves $\mathrm{d} 1, \mathrm{~d} 2, \mathrm{~d} 3$, total scenario I gives the partial sums in the respective sections (see B) respectively the overall sum of them; (F) rb / s, the rate of bees released per second, calculated with the reference period of $33 \mathrm{~ms}$; abscissa, time in s; zero is defined by the time of contact the bee eater takes at nest one with its beak; at this time the spray of bees emitted from nest one had already started. 


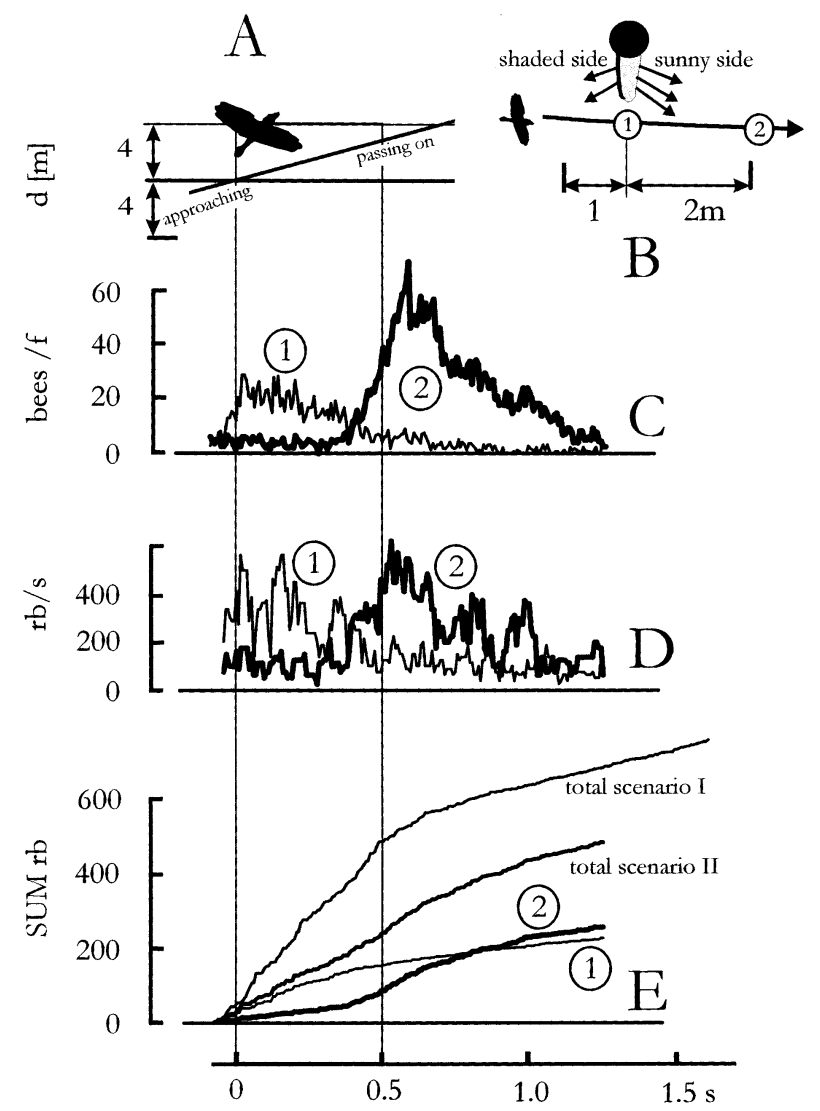

Figure 3. How a blue-bearded bee eater (Nyctyornis athertoni) attacked a colony of giant honeybee (Apis dorsata) and how the members of both sides of the nest reacted (scenario II); (A) time-distance profile of the flight course of the raiding bee eater, $0 \mathrm{~m}$ is defined as the position just below the rim of the nest; (B) sketch of the nest site; the left (1) shaded side of the nest was directly threatened by the bee eater's raid and reacted first, the right (2) sunny side reacted as well, but delayed; 1, 2 give the times where the respective nest sides started to release bees; $(\mathbf{C})$ bees / $\mathrm{f}$ are counts of flying bees per frame which were released from the respective nest sides $(1,2) ;(\mathbf{D}) \mathrm{rb} / \mathrm{s}$, the rate of bees released per second from the respective nest side $(1,2)$, calculated with the reference period of $50 \mathrm{~ms}$; (E) SUM rb, the sum of bees released (see method) from the respective nest sides $(1,2)$, total scenario II gives the total sum of those released bees; total scenario I, the sum of released bees at the whole site in scenario I (see Fig. 2); abscissae, time in s; zero is defined by the time the bee eater is just below the nest; at this time the spray of bees emitted from the shaded nest side had already started.

were observed at their sunny side. Nest one faced with its sunny side to the bee eater, nest two with its shaded side. In scenario II only the rim of a nest is displayed from below (Fig. 3), the bee eater passed under it. The responses of the shaded and the sunny side of the nest to this raid were observed.

\subsection{Data evaluation}

From video copies of the film we assessed the positions of the beaks of the raiding blue-bearded bee eaters (Nyctyornis athertoni) and of the thoraces of the bees during the defence release. This was 
achieved by division of subsequent video images and filtering as standard routines of the image analysis software (OPTIMAS, Flir). This produced sufficient contrast to differentiate the flying bees from the background comprising foliage and the nest itself.

The approach chosen, however, does not allow either direct assessment of the recruitment of guard bees nor their release. The emitter bees could hardly be identified individually in successive frames, although the same individual bees are displayed in successive frames (bees / f in Figs. 2, 3). Bees which set off from the nest will vanish after a while due to different flight directions, to foreground objects like foliage, branches or nests, or they will simply get out of the frame. We measured the strength of the response of the colony by estimating the release of bees from the increase of bees (negative differences were dismissed) between successive frames $(7.67 \mathrm{~ms})$, and summing these up to calculate the cumulated release over time (sum rb in Figs. 2, 3 ). Based on 5-frame intervals ( $33.3 \mathrm{~ms}$ ) the rate of release (rb / $\mathrm{s}$ in Figs. 2, 3) was calculated. This calculation is useful for the documentation of the release of defence forces as long as the spreading bees do not disappear out of the sample frame. If this happens, the cumulative release is underestimated. Therefore, the first $500 \mathrm{~ms}$ of observation produce reliable results, as in this period of time most of the emitted bees were still displayed in the three sections $\mathrm{d} 1, \mathrm{~d} 2, \mathrm{~d} 3$ around the nests which are defined regarding the distances 30-100, 100-200 and $200-400 \mathrm{~cm}$.

\section{RESULTS}

Large aggregations of honeybee (Apis dorsata) colonies will attract predatory birds such as bee eaters, drongos, swallows or honey buzzards. Among them, the bluebearded bee eater (Nyctyornis athertoni) routinely provokes bee colonies to release large numbers of bees which pursue and attack the bird. The bee eaters approach beneath the cover of vegetation and snatch off or even wipe bees off the curtain of the colony. Raiding flights happened just after sunrise and before sunset for half an hour, at a frequency of one to several times per minute. We investigated two scenarios of interactions between bee eater and giant honeybee colonies.

\subsection{Scenario I: the bee eater passed between two nests: both released defence forces}

In our selected example (Figs. 1, 2) the bee eater approached nest one at a speed of $4 \mathrm{~m}$ per s. This colony started the release of defence forces with a speed of $7 \mathrm{~m}$ per second when the bee eater was $30 \mathrm{~cm}$ from the nest, $80 \mathrm{~ms}$ before it had touched the nest with its beak (referred to as bird position 1 in Fig. 2B, and as $t=-0.08 \mathrm{~s}$ in Fig. 2A). It seemed as if the colony had sprayed off bees, well directed to the predatory bird. Up to 120 bees were counted around nest one (Fig. 2C curve one) in section d1. Emission summed up to 200 bees in the course of $250 \mathrm{~ms}$ after the onset of the response (Fig. 2D curve one). Considering all three sections (d1-d3: Fig. 2B), the release of the defence forces can be reliably estimated for the double period $(0.5 \mathrm{~s})$. From this time onwards the bees became more and more dispersed and outside the frame. This is illustrated by the cumulated release (Fig. 2E), which is linear in this initial period to the sum of 500 bees; subsequently the graph bends and shows a lower inclination until it reaches more than 700 bees after $1.5 \mathrm{~s}$. Considering the fact that this result underestimates the dimension of release, at least for the process after the time of $0.5 \mathrm{~s}$ (see methods), we may expect a defence force of at least 700-800 bees from nest one alone. As this colony comprised about thirty thousand individuals, it thus had gathered 2-3 per cent of its members as a counter-attacking force. The release per second reached 400-600 bees (Fig. 2F). 
Three hundred ms after the onset of the emission by colony one, the neighbouring colony two also released bees from its lower rim zone (Fig. 2D, curve two) during the subsequent second. These bees spread straight downwards, and were not directed to the vanishing predatory bird. This release was much smaller, summing up to around 100 bees, counted in distance region $\mathrm{d} 1$ of nest two. At that time, the bee eater was already $1 \mathrm{~m}$ above the threatened colony and out of the view of both colonies.

One second after the attack of the bird, the total number of bees present in the sections $\mathrm{d} 1-\mathrm{d} 3 \mathrm{had}$ declined to 20 bees, only a small part of them still came from nest one (Fig. 2C). The majority of the defence forces patrolled in the canopy, and only a small group of guard bees still followed the bird. The defence forces of both nests obviously joined the canopy patrol which was observed during the whole period of half an hour in which the bee eaters continuously attacked the colonies.

\subsection{Scenario II: the bee eater passed under a nest: both sides of the nest sequentially responded with the release of defence forces}

The bee eater approached the nest (Fig. 3) at a speed of $6 \mathrm{~m}$ per second. It threatened the shaded side of the nest, by visual cues and probably also mechanically by the strong wave front of the air stream it generated. The opposite sunny side of the nest remained unthreatened as long as the bird was approaching; afterwards, the visual cues of the vanishing bird could have affected this side of the colony.

The colony started to release its defence force from the shaded side (Fig. 3C curve 1, starting time is referred to as bird position 1 in Fig. 3B), when the bird was going to pass the lower rim of the nest. The sunny side of the colony followed when the bird was already more than $2 \mathrm{~m}$ away from the nest (referred to as bird position 2 in Fig. 3B, Fig. 3C curve 2), $400 \mathrm{~ms}$ after the bees might have first seen the bird. Within $0.5 \mathrm{~s}$, the bees had reached flight speeds of $4.55 \pm$ $1.42 \mathrm{~m} / \mathrm{s}(n=1332)$, around 150 bees were released from the shaded side of the nest within $0.5 \mathrm{~s}$ (Fig. 3E, curve 1), and more than 200 bees from its opposite part also within such a period (Fig. 3E, curve 2), summing up to 500 bees within $1.2 \mathrm{~s}$ regarding the whole nest. This colony response was smaller than that of nest one in scenario I, and the releasing rate (Fig. 3D) was in both parts of the nest 400-600 bees per s, which is similar to scenario I (Fig. 3F).

\section{DISCUSSION}

\subsection{Release of defence forces in Apis dorsata}

It is assumed [18] that predation has extensively shaped the behaviour of the honeybee species of tropical Asia. This is especially true for the various forms of defence behaviours of giant honeybees, which are mainly produced by the bees of the outer curtain of the nest. A prominent example is shimmering behaviour $[2,17]$, which is thought to hinder intruders, in particular wasps, from landing on the curtain (Kastberger, unpublished data), but also to confuse, frighten or simply mesmerise potential enemies $[2,9,11,18,20]$. Such cascadic behaviours have been shown to alarm the colony by Nasonoff scenting [7]. Another form of highly co-ordinated colony action, involving not only the surface bees but all the layers of the bee curtain, is the rearingup response, which is predominant after mechanical disturbance, before a mass release of defence forces is initiated. It is also a wave-like process, but much slower than the shimmering behaviour; the individuals of all layers stretch their bodies from the comb for several seconds, activate their flight muscles and buzz their wings without taking off. This causes the colony to swell and emit a roaring sound [14], providing visual and acoustic signals, which appears to effectively repel mammal aggressors in particular. 
It is part of the daily routine of the colonies, particularly in aggregations, to protect their nests from predatory birds. Thousands of guard bees may be released in a sudden cascade within a fraction of a second, which are in most cases also directed to the invader. The colonies especially prepare themselves for such mass counterattacks in times of increased predator pressure, such as when bee eaters fly forays at nests. In an undisturbed colony it takes several minutes to mobilise a large group of guard bees (Kastberger, unpublished data), which can be released as a defence force. For the risky operation of a counter-attack, the colony dismisses only a relatively small fraction of itself. In a medium-sized nest $1.2 \mathrm{~m}$ wide, only several hundred bees were released, which comprise only 1 to 3 per cent of the colony. Bigger colonies, up to $2 \mathrm{~m}$ in width, may send respectively more, possibly even a few thousand bees [14].

The mass release of guard bees is undoubtedly the most potent strategy of the giant honeybees to repel vertebrate predators. Although this trait stamps this bee as one of the most ferocious stinging insects on earth [14], in some special cases it is not much protection for the threatened colony. Blue-bearded bee eaters (Nyctyornis athertoni) in particular, have an ingenious hunting behaviour. By provoking honeybee colonies, these birds derive direct benefit from the counter-attacking forces. After each foray, the bees pursue the bird until it settles on a twig, and while the bees try to sting it, they are caught and eaten. Throughout their aggregation season, giant honeybees may face an increasing predatory pressure by bee eaters as well as by honey buzzards [18-20]. In particular, foraging honey buzzards regularly destroy the combs, which causes the respective threatened colonies to abscond [9, own observations in Assam and Nepal].

\subsection{Is there any intercolonial group defence?}

Joint defence operations in aggregated Apis dorsata colonies have been postulated by several authors $[12,13,15,18]$. We found in Apis dorsata two lines of evidence suggesting that colonies or parts of them, which were not directly threatened by visual cues or even by mechanical disturbance of predatory birds, participated in the defensive action of the directly threatened bees.

The first evidence refers to a nest (Fig. 2) which was $2 \mathrm{~m}$ away from the flight path of a raiding bee eater and thus it was not as directly threatened as the other colony which was closer to the bird. Nevertheless, this unthreatened colony joined, though delayed and with less strength, the defending force of the threatened colony. Because honeybee colony defence is incited by alarm pheromones [3, 4, 7, 13], it is most reasonable that the guards released by the threatened colony brought their alarm pheromones directly over the other nest, which then triggered the intercolonial group response.

The second evidence refers to the two sides of a single nest (Fig. 3). It is unlikely that both sides of a nest have sufficiently close contact to synchronize the release of forces within a fraction of a second. It is more likely that each side is independent in preparing for defence. Furthermore, a predatory bird, after having approached and threatened one side of a colony, may well leave the opposite side unaffected. Therefore it is expected that the nest does not respond simultaneously from both sides to the predatory bird; in our example it recruited two different groups of bees within $400 \mathrm{~ms}$.

\subsection{Why a non-directly threatened part of a nest may participate in defence response}

The continuous forays of the predatory birds may have two effects: on the one hand, they may sensitise the colonies, preparing them to release forces; on the other hand, they may habituate the bees, reducing the threshold distance to start repelling activities. Under such conditions we observed in colony aggregations that not only bees 
which had been directly threatened by predatory birds participated in defence forces but also non-directly threatened ones (Figs. 2, 3). The responses of the two categories of nest regions involved different numbers of bees and different delay times.

Magnitude of defence forces. The colony's readiness for mass flight $[6,7]$ and mass defence (Kastberger, unpublished data) is determined by the respective diurnal changes in the exposure of its various parts (such as the mouth zone [14], the more quiescent parts, the more sunny or the more shaded nest sides) to temperature, light, wind or rain, which causes an obvious asymmetry in the nest regarding the mobilisation of defence forces. This may explain the results of scenario I: this side of nest two which faced the predator and responded with a release of a small defence force, was the shaded one. It was probably less mobilised initially. In scenario II the shaded side was directly threatened by the bird and responded less than the more active sunny region which was more prepared to release guards.

Trigger sources. The directly threatened parts of the nests always responded first. It is likely that visual cues of the approaching bird trigger the release of the defence force. In scenario $\mathrm{I}$ it is demonstrated that the release started when the bird was $30 \mathrm{~cm}$ away from the nest's rim. But why do the non-directly threatened bees of the same colony or of different colonies participate in the defence response which is going on, and why does this happen with a $400 \mathrm{~ms}$ delay? In particular, if bees would only respond to visual cues, all colonies in an aggregation (which even may nest side to side), which are on standby for a bird's attack and located near the route of the foraying bird, are expected to release defence forces. However, this had never been found although hundreds of bee eater forays had been observed. In both scenarios the nondirectly threatened bees responded significantly later, $400 \mathrm{~ms}$ after the first release of guard bees of the directly threatened part.
Therefore it can be assumed that visual sensitation is unlikely to trigger the defence response of unthreatened bees.

Alarm Pheromone as possible trigger source? In particular, the behaviour of nest two in scenario I (Fig. 2) gives here a strong evidence that the release of defence forces could be triggered by alarm pheromone [ 3 , $4,6,13]$. The bees on the surface of both nests (one, two) must have seen the approaching bird in a similar way and could have released defence forces at the same time and in similar strength. The foraying bird certainly induced a shock wave of the air stream mainly at its primary target, at nest one; nest two could have been just touched by it, at the same time and much weaker. Therefore neither visual cues of the foraying bird nor the air stream generated by it are trigger sources to arouse the nest two. The defence response of nest two could have been triggered under that condition only by the dispersing bees of nest one which brought alarm pheromone directly to nest two (a passive spread of alarm pheromone from nest one to nest two within $400 \mathrm{~ms}$ is unlikely, in particular, because the air stream generated by the bird was directed upwards). This would explain why the release of nest two started just after the bees of nest one had reached it [9].

\subsection{Intercolonial group defence favours colony aggregation}

Two more proximate theories on honeybee defence behaviour attempt to explain why colony aggregation may have been selected in the course of evolution. The first theory is a variant of the general "dilution effect" [1] and postulates that the chance of being attacked by predators is reduced for an individual colony if it occurs in a group which remains to be investigated for giant honeybees $[12,15,18,19]$. The second, the "intercolonial group defence theory" postulated by several authors $[5,12,18]$, has now been demonstrated for giant honeybee 
colonies exposed to bee eaters. The evidence presented is twofold. Firstly, the forces released from threatened colonies patrol the whole canopy and protect neighbouring nonthreatened nests. Second, a colony (scenario I, Fig. 2) or even only a part of a colony (scenario II, Fig. 3) may not only be alerted [18] but can also participate in group defence, even though it has not been directly attacked by the predator.

\section{ACKNOWLEDGMENTS}

We thank Richard Beckett (Pietermaritzburg), Randall Hepburn (Grahamstown), Werner Loher (Berkeley), Ben Oldroyd (Sydney), Gard W. Otis (Guelph), Paul Reddish (Bristol), Stefan Fuchs (Oberursel) and Anton Stabentheiner (Graz) for critically reading the first draft of the manuscript and valuable comments, Ian McCarthy (Bristol) for filming, and Chetri Bopal for logistic help in Assam. Supported by the Austrian Scientific Foundation, grant P13210-BIO and epo-Film (Vienna).

Résumé - Interaction proie-prédateur entre les guêpiers (Nyctyornis athertoni Jardine et Selby 1830) et les abeilles géantes (Apis dorsata Fabricius 1798). Il est admis que la prédation a largement façonné le comportement des espèces d'Apis en Asie tropicale. L'une des stratégies les plus impressionnantes est le lâcher en masse d'abeilles pour repousser les prédateurs. Nous avons étudié le comportement que les guêpiers (Nyctyornis athertoni) déclenchent chez les abeilles géantes (Apis dorsata) par leurs vols d'attaque. Nous avons filmé durant cinq jours les relations prédateur-proie dans un rassemblement de 50 colonies sur un arbre à abeilles (Trewia nudiflora) en Assam (Inde) à l'aide d'un Arriflex à 150 images/s. Pour l'analyse du comportement nous avons sélectionné deux scénarios. Dans le scénario I, le guêpier passe en volant parallèlement à un nid (Fig. 2A) et ne menace donc qu'un côté du nid, dans ce cas le côté ensoleillé ; dans le scénario II, il passe sous un nid, perpendiculairement au rayon, et déclenche des essaims d'attaque des deux côtés du rayon
(Fig. 3A). Dans le scénario I, nous avons compté plus de 700 abeilles qui ont été lâchées, ce qui correspond à 2-3\% des membres de la colonie. Les abeilles lâchées ont suivi l'oiseau et ont continué à patrouiller plus haut dans la canopée. Cela constitue la première preuve d'une défense de groupe intercolonies chez $A$. dorsata : une colonie non directement menacée par un oiseau participe à la réaction de défense avec le nid menacé. Dans le scénario II, plus de 100 abeilles ont été libérées sur le côté du rayon qui était directement menacé par l'oiseau (côté à l'ombre) et plus de 200 abeilles sur l'autre côté du rayon (côté ensoleillé), d'où seul pouvait être vu l'oiseau qui s'éloignait. Les abeilles du côté à l'ombre se sont impliquées un peu moins que celles qui étaient sur le côté ensoleillé. Les régions du nid plus actives ont pu visiblement recruter plus vite et former une plus grosse troupe d'attaque. Nous discutons la façon dont des colonies, ou des portions de colonies, qui ne sont pas directement attaquées ni menacées, peuvent être incitées à lâcher en masse des gardiennes. Il se peut qu'elles portent leur phéromone d'alarme directement aux nids ou aux parties de nids non menacés, mais le nuage de phéromone pourrait aussi être étendu par les flux d'air générés par les guêpiers en chasse.

\section{Apis dorsata / lâcher en masse / guêpier / interaction prédateur-proie / comporte- ment de défense}

Zusammenfassung - Räuber-Beute-Interaktionen zwischen dem Blaukehlspint (Nyctyornis athertoni Jardine und Selby 1830) und den Riesenhonigbienen (Apis dorsata Fabricius 1798). Wir untersuchten das Verhalten, das Blaukehlspinte ( $\mathrm{Nyc}$ tyornis athertoni) durch ihre Angriffsflüge bei Riesenhonigbienen (Apis dorsata) auslösen. In einer Aggregation von 50 Kolonien filmten wir durch fünf Tage auf einem Bienenbaum in Assam (Indien) mit einer Arriflex bei 150 Bildern pro s. Für die Auswertung wählten wir zwei Szenarien 
aus. Im Szenario I streifte der Bienenfresser parallel an einem Nest vorbei und bedrohte dadurch nur diese, besonnte, Nestseite; im Szenario II kam er von der Seite an das Nest heran und löste Angriffsschwärme an beiden Seiten der Wabe aus. Im Szenario I zählten wir mehr als 700 Bienen, die freigesetzt wurden, was 2-3 Prozent der Koloniemitglieder beträgt. Die freigesetzten Bienen folgten dem Vogel und patrollierten noch weiter in der Wipfelregion des Baumes. In diesem Zusammenhang gelang der für Apis dorsata erste Nachweis, dass sich eine nicht direkt vom angreifenden Vogel bedrohte Kolonie an der Verteidigungsreaktion des bedrohten Nests beteiligte. Im Szenario II kamen mehr als hundert Bienen von der Kolonie auf jener Seite frei, die vom angreifenden Vogel direkt bedroht war, und mehr als 200 Bienen von der gegenüberliegenden Nestseite, die nur den davonfliegenden Vogel sehen konnte. Bienen an der eher beschatteten Nestseite beteiligen sich dabei weniger stark als an der besonnten Seite. Die aktiveren Nestregionen können sich offenbar schneller und eine größere Angriffstruppe rekrutieren. Es wird diskutiert, wie Kolonien, oder Teile davon, die nicht direkt angegriffen oder bedroht waren, dazu angeregt werden können, Wächterbienen in Massen freizusetzen. Diese könnten ihr Alarmpheromon direkt zu den nicht-bedrohten Nestern bzw. Nestteilen tragen, aber es könnte auch die Pheromonwolke durch die von den jagenden Bienenfressern generierten Luftströme verbreitet werden.

\section{Apis dorsata / in Massen freisetzen / Blau- kehlspint / Räuber-Beute-Interaktionen / Verteidigungsverhalten}

\section{REFERENCES}

[1] Alcock J., Animal Behavior: an evolutionary approach, Sinauer Associates, Inc., Mass., 1989.

[2] Butler C.G., The world of the honeybee, Collins, London, 1962

[3] Collins A.M., Rinderer T.E., Daly H.V., Harbo J.R., Pesante D.G., Alarm pheromone production by two honeybee (Apis mellifera) types, J. Chem. Ecol. 115 (1989) 1747-1756.

[4] Free J.B., Pheromones of Social Bees, Chapman \& Hall, London 1987.

[5] Hepburn H.R., Radloff S.E., Honeybees of Africa, Springer, Berlin 1998.

[6] Kastberger G., Winder O., Hötzl T., Raspotnig G., Behavioural features of a periodic form of massed flight activity in the giant honeybee Apis dorsata, Apidologie 27 (1996) 381-395.

[7] Kastberger G., Winder O., Biswas S., Raspotnig G., Evidence of Nasonov scenting in colony defence of the Giant honeybee Apis dorsata, Ethology 104 (1998) 27-37.

[8] Kastberger G., Biswas S., Mechanisms in the cascadic alarming response of a giant honeybee colony, Zoology 101 (1998), Suppl. I, 48.

[9] Kastberger G., The magic trees of Assam. Documentary film about the biology of the giant honeybees Apis dorsata, narrated by Sir David Attenborough, produced by National Geographic, ZDF, ORF, epo-film, released November 1999 , Web address: http://www.zdf.de/wissen/wwelt/ 39150/index.html.

[10] Kloft W., Schneider P., Gruppenverteidigungsverhalten bei wildlebenden Bienen (Apis cerana Fabr.) in Afghanistan, Naturwissenschaften 56 (1969) 219.

[11] Koeniger N., Fuchs S., Zur Kolonieverteidigung der asiatischen Honigbienen, Z. Tierpsychol. 37 (1975) 99-106.

[12] Lindauer M., Über die Verständigung bei Indischen Bienen, Z. Vergl. Physiol. 38 (1956) 521-557.

[13] Moritz R.F.A., Southwick E.E., Bees as Superorganisms, Springer, Berlin, 1992.

[14] Morse R.A., Laigo F.M., Apis dorsata in the Phillippines, Philipp. Assoc. Entomol., 1969.

[15] Oldroyd B., Smolenski A., Lawler S., Estoup A., Crozier R., Colony aggregations in Apis mellifera L., Apidologie 26 (1995) 119-130.

[16] Roepke W., Beobachtungen an indischen Honigbienen insbesondere an Apis dorsata, Meded Landbouwhooge-School Wageningen 34 (1930) $1-28$.

[17] Sakagami S.F., Preliminary report on the specific difference of behaviour and other ecological characters between European and Japanese honeybees, Acta Hymenopt. 1 (1960) 171-198.

[18] Seeley T.D., Seeley R.H., Akratanakul P., Colony defence strategies of the honey bees in Thailand, Ecol. Monogr. 52 (1982) 43-63.

[19] Underwood B.A., The natural history of Apis laboriosa, M.Sc. thesis, Cornell University, 1986.

[20] Underwood B.A., The behaviour and energetics of high-altitude survival by the Himalayan honeybee Apis laboriosa, Ph.D. thesis, Cornell University, 1990. 